\title{
PROFIL KADAR HEMOGLOBIN DAN INDEKS ERITROSIT PADA PEROKOK AKTIF DI KELURAHAN TANJUNG PINANG KOTA PALANGKA RAYA
}

\author{
Rinny Ardina", Vira Anisa Monica ${ }^{2}$ \\ ${ }^{1}$ Dosen Program Studi D-III Analis Kesehatan, Fakultas IImu Kesehatan, \\ Universitas Muhammadiyah Palangkaraya, Palangka raya, Kalimantan Tengah \\ ${ }^{2}$ Mahasiswa Program Studi D-III Analis Kesehatan, Fakultas IImu Kesehatan, \\ Universitas Muhammadiyah Palangkaraya, Palangka raya, Kalimantan Tengah \\ e-mail : rinyardina@gmail.com
}

\begin{abstract}
ABSTRAK
Perokok aktif merupakan orang yang merokok secara aktif atau terus-menerus. Populasi perokok di Provinsi Kalimantan Tengah adalah 26,5\%. Rokok mengandung bahan beracun dan berefek candu. Adanya tar dan radikal bebas dari asap rokok dapat menyebabkan hemolisis eritrosit. Selain itu, kandungan dari asap rokok juga dapat menyebabkan peningkatan kadar hemoglobin yang dimediasi oleh paparan karbonmonoksida (CO) yang berikatan dengan hemoglobin membentuk carboxyhemoglobin ( $\mathrm{HbCO}$ ). Tujuan dalam penelitian ini adalah untuk mengetahui profil kadar hemoglobin dan indeks eritrosit pada perokok aktif di kelurahan Tanjung Pinang Kota Palangka Raya. Metode yang digunakan dalam penelitian ini adalah metode observasional study pendekatan deskriptif yang bertujuan untuk mengetahui profil kadar hemoglobin dan indeks eritrosit pada perokok aktif. Jumlah sampel yang didapatkan adalah sebanyak 28 orang dengan teknik purposive sampling. Pemeriksaan kadar hemoglobin dan indeks eritrsoit dilakukan dengan metode otomatis menggunakan Hemotology Analyzer. Hasil penelitian menunjukkan sebesar $14,2 \%$ perokok aktif memiliki kadar hemoglobin rendah $(<13,0 \mathrm{~g} / \mathrm{dl})$, dan $85,7 \%$ kadar hemoglobin normal. Berdasarkan indeks eritrosit didapatkan $7,1 \%$ dengan anemia mikrositik hipokrom (MCV dan $\mathrm{MCH}$ rendah, sedangkan $\mathrm{MCHC}$ normal) disertai dengan kadar hemoglobin rendah dan sebesar 92,8\% didapatkan indeks eritrosit normal.
\end{abstract}

Kata Kunci: Perokok Aktif, Hemoglobin, Indeks Eritrosit, Hematology Analyzer

\begin{abstract}
Active smokers are people who are smoking continuously. The population of active smokers in Central Kalimantan was $26,5 \%$ in 2013. Cigarettes contain many of toxic and addictive chemicals. The presence of tar and free radicals from cigarette smoke can cause erythrocyte hemolysis. In addition, the content of cigarette smoke can also cause an increase of hemoglobin levels that mediated by exposure of Carbonmonoxide (CO). $\mathrm{CO}$ binds avidly to hemoglobin to form carboxyhemoglobin ( $\mathrm{HbCO}$ ). This study aims to give description of hemoglobin level and erythrocyte indices in active smokers in Kelurahan Tanjung Pinang, Palangka Raya. Descriptive observational method with cross sectional design was used in this study. Sample obtained by 28 people with purposive sampling technique with criteria such as active smokers, men, working as farmers, laborers
\end{abstract}


or fish farmers and not alcoholic. Examination of hemoglobin level and erythrocytes indices was done by hematology analyzer. The result showed that 4 people $(14,2 \%)$ had low hemoglobin level and 4 people $(85,7 \%)$ was normal. Based on erythrocytes indices, 2 people $(7,1 \%)$ with hypochromic microcytic anemia (low MCV, low $\mathrm{MCH}$ and normal $\mathrm{MCHC}$ ) and also low hemoglobin level. While 26 people $(92,8 \%)$ had normal erythrocyte indices.

Keywords: Active Smokers, Hemoglobin, Erythrocyte Indices, Hematology Analyzer

\section{PENDAHULUAN}

Perilaku merokok penduduk yang berusia 15 tahun ke atas masih belum mengalami penurunan dari tahun 2007 hingga 2013, bahkan cenderung meningkat dari $34,2 \%$ pada tahun 2007 menjadi 36,3 \% pada tahun 2013. Pada tahun 2013 terdapat 64,9\% laki-laki masih menghisap rokok dan rerata jumlah batang rokok yang dihisap adalah sekitar 12,3 batang per hari [1] [2]

Riset Kesehatan Dasar (Riskesdas) tahun 2013 menemukan bahwa rerata proporsi perokok saat ini di Indonesia adalah 29,3\% dan di Kalimantan Tengah populasi perokok tercatat cukup tinggi yaitu 26,5\%. Berdasarkan kelompok umur proporsi terbanyak perokok aktif setiap hari pada umur 30-34 tahun sebesar 33,4\%, umur 35-39 tahun sebesar 32,2\%, sedangkan berdasarkan jenis kelamin pada laki-laki lebih banyak (47,5\%) dibandingkan perokok perempuan (1,1\%). Berdasarkan jenis pekerjaan diketahui petani, nelayan, dan buruh merupakan proporsi perokok aktif terbesar (44,5\%) dibandingkan kelompok pekerjaan lainnya [1]
Asap rokok mengandung beberapa zat yang berbahaya. Selain karsinogen dan kokarsinogen, 40\% kandungan rokok adalah bahan beracun dan berefek candu. Adanya tar dan radikal bebas dari asap rokok dapat menyebabkan hemolisis eritrosit[3]. Efek hematotoksisitas timbal dari asap rokok juga dapat menghambat sebagian besar enzim yang berperan dalam biosintesa heme. Radikal bebas yang berlebihan akan meningkatkan aktivitas lipid peroksidase (LPO) dan menurunkan status antioksidan eritrosit yang menyebabkan kerusakan pada membran eritrosit sehingga eritrosit akan lebih mudah lisis dan akibatnya akan terjadi penurunan jumlah eritrosit[4].

Selain itu, rokok menyebabkan penurunan kadarhemoglobin $(\mathrm{Hb})$ yang dimediasi oleh paparan carbonmonoksida (CO) yang berikatan dengan hemoglobin membentuk carboksihemoglobin ( $\mathrm{HbCO}$ ). CO yang dihasilkan oleh asap rokok memiliki kecenderungan yang kuat untuk berikatan dengan hemoglobin dalam eritrosit, ikatan ini 210-300 kali lebih kuat daripada ikatan hemoglobin dengan oksigen 
(Oksihemoglobin). Tingkat hemoglobin ratarata dan tingkat $\mathrm{HbCO}$ meningkat secara progresif dengan jumlah rokok yang dikonsumsi per hari.Selain jumlah rokok yang dihisap per hari, durasi paparan kronis terhadap $\mathrm{HbCO}$ juga berkorelasi dengan perkembangan polisitemia. Diketahui kadar gas $\mathrm{CO}$ dalam darah pada orang bukan perokok kurang dari $1 \%$, sementara dalam darah perokok mencapai 4-15\% [5].

Penelitian Ibrahim (2014) menyatakan bahwa adanya peningkatan yang signifikan pada jumlah eritrosit, $\mathrm{Hb}$, Packed Cell Volume (PCV) dan Mean Cospuscular Hemoglobin ( $\mathrm{MCH})$ pada perokok dibandingkandengan non-perokok dari kelompok usia yang sama dan peningkatan tidak signifikan pada nilai Mean Cospuscular Volume (MCV) dan Mean Cospuscular Hemoglobin Concentration (MCHC) [6]

Adapun lokasi yang dipilih untuk dapat memberikan profil tentang kadar hemoglobin dan indeks eritrosit pada perokok aktif ialah di Kelurahan Tanjung Pinang, tepatnya di perumahan penduduk di Jalan Bengaris. Lokasi ini diketahui penduduknya cukup banyak berprofesi sebagai petani, buruh dan penambak ikan yang juga merupakan perokok aktif dan ini telah dikategorikan sebagai perokok aktif terbesar berdasarkan jenis pekerjaan.

\section{METODOLOGI}

\section{Rancangan Penelitian}

Penelitian ini menggunakan metode observasional deskriptif, yaitu suatu metode yang digunakan untuk menggambarkan kadar hemoglobin dan indeks eritrosit pada perokok aktif di Kelurahan Tanjung Pinang Kota Palangka Raya yang dilakukan dengan menempuh langkah-langkah: pengumpulan data, klasifikasi, dan pengolahan/analisis data.

\section{Populasi dan Sampel}

\section{Populasi}

Populasi pada penelitian ini adalah orang yang menghisap asap rokok secara langsung dan terus menerus yang tinggal di Jl. Bengaris RT. 001/RW. 003 Kelurahan Tanjung Pinang Kota Palangka Raya.

\section{Sampel}

Pada penelitian ini sampel diambil dengan menggunakan teknik purposive sampling dengan kriteria: responden merupakan perokok aktif, berjenis kelamin laki-laki, tidak mengkonsumsi alkohol, bekerja sebagai petani, buruh, atau penambak ikan, dan bersedia untuk menjadi responden dalam penelitian. Jumlah sampel yang diperoleh yaitu sebanyak 28 sampel yang ditentukan dengan menggunakan rumus Lemeshow (2010) [7] sebagai berikut:

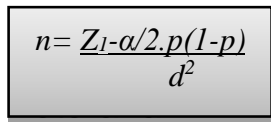

$\mathrm{n}$ : jumlah sampel 
$\mathrm{p}$ : perkiraan proporsi $(0,5)$

$\mathrm{d}$ : presisi absolut (13\%)

$Z$ 1- $\alpha / 2$ : statistic $Z(Z=1,96$ untuk $\alpha=0,05)$

\section{Teknik Pengumpulan Data dan} Instrumen Penelitian

\section{Observasi}

Observasi dilakukan untuk melihat jumlah populasi penelitian dan mengetahui jenis pekerjaan dari warga RT 001/RW 003di Kelurahan Tanjung Pinang Kota Palangka Raya.

\section{Wawancara}

Wawancara dilakukan secara terstruktur dengan bantuan angket yang berisi pertanyaan-pertanyaan terkait status kesehatan, gaya hidup, dan penggunaan pestisida dari responden yang berguna untuk melengkapi informasi dalam penelitian.

\section{Alat dan Bahan Sampling Darah Vena}

Tabung vakum ungu ( $\mathrm{K}_{3} \mathrm{EDTA}$ ), spuit $3 \mathrm{cc}$, tourniquet, dan kapas alkohol $70 \%$.

\section{Alat dan Bahan Pemeriksaan Hemoglobin dan Indeks eritrosit}

Hematology Analyzer, reagen cell clean, stromalyse, dan sampel darah EDTA.

\section{Pengambilan dan Perlakuan Sampel Darah}

Pengambilan dan perlakuan terhadap sampel darah dilakukan sesuai prosedur operasional standar dari Departemen Kesehatan RI tahun 2008 [8].

\section{Pemeriksaan Sampel dengan Hematology Analyzer}

Pengukuran kadar hemoglobin dengan metode ini yaitu besi pada hemoglobin diubah dari bentuk ferro $\left(\mathrm{Fe}^{++}\right)$ menjadi ferri $\left(\mathrm{Fe}^{+++}\right)$sehingga membentuk methemoglobin yang berwarna stabil. Intensitas warna yang melewati kuvet diukur secara spektrofotometri pada panjang gelombang tertentu. Hasilnya akan sebanding dengan konsentrasi hemoglobin dalam darah [9] Nilai indeks eritrosit dilakukan langsung oleh alat, dimana alat akan mengukur jumlah eritrosit, hemoglobin, dan hamatokrit terlebih dahulu [10]

\section{Teknik Analisa Data}

Teknik analisis data yang digunakan adalah analis univariate yang bertujuan untuk menjelaskan karakteristik dari kadar hemoglobin dan indeks eritrosit pada perokok aktif yang tinggal di Jl. Bengaris Kelurahan Tanjung Pinang Kota Palangka Raya.

\section{HASIL DAN PEMBAHASAN}

\section{Profil Kadar Hemoglobin Berdasarkan Karakteristik Sampel}

Karakteristik berdasarkan umur, lama merokok, jumlah rokok yang dihisap dan waktu istirahat adalah sebagai berikut:

Tabel 1. Profil Kadar Hemoglobin Berdasarkan Karakteristik

\begin{tabular}{|c|c|c|c|c|c|c|}
\hline \multirow{3}{*}{$\begin{array}{c}\text { Karakteristik } \\
\text { Sampel }\end{array}$} & \multicolumn{4}{|c|}{ KADAR HEMOGLOBIN } & \multirow{3}{*}{ JUMLAH } & \multirow{3}{*}{$\%$} \\
\hline & \multicolumn{2}{|c|}{ NORMAL } & \multicolumn{2}{|c|}{ RENDAH } & & \\
\hline & $\mathbf{N}$ & $\%$ & $\mathbf{n}$ & $\%$ & & \\
\hline \multicolumn{7}{|l|}{ Umur } \\
\hline 20-30 Tahun & 7 & 25 & 1 & 3,5 & 8 & 28,5 \\
\hline 31-40 Tahun & 10 & 35,7 & 1 & 3,5 & 11 & 39,2 \\
\hline 41-50 Tahun & 4 & 14,2 & - & - & 4 & 14,2 \\
\hline
\end{tabular}




\begin{tabular}{lcccccc}
\hline 51-60 Tahun & 3 & 10,7 & 2 & 7,1 & 5 & 17 \\
\hline Total & $\mathbf{2 4}$ & $\mathbf{8 5 , 7}$ & $\mathbf{4}$ & $\mathbf{1 4 , 2}$ & $\mathbf{2 8}$ & $\mathbf{1 0 0}$ \\
\hline Lama & & & & & & \\
Merokok & 7 & 25 & 2 & 7,1 & 9 & 32,1 \\
1-10 Tahun & 9 & 25 & - & - & 9 & 32,1 \\
11-20 Tahun & 8 & 28,5 & 2 & 7,1 & 10 & 35,7 \\
>20 Tahun & & & & & & \\
\hline Total & $\mathbf{2 4}$ & $\mathbf{8 5 , 7}$ & $\mathbf{4}$ & $\mathbf{1 4 , 2}$ & $\mathbf{2 8}$ & $\mathbf{1 0 0}$ \\
\hline Jumlah rokok & & & & & & \\
yang dihisap & & & & & & \\
per hari & & & & 3,5 & 8 & 28,5 \\
1-10 Batang & 7 & 25 & 1 & 3,5 & 10 & 35,7 \\
11-20 Batang & 9 & 32,1 & 1 & 3,5 \\
$>$ 20 Batang & 8 & 28,5 & 2 & 7,1 & 10 & 35,7 \\
\hline Total & $\mathbf{2 4}$ & $\mathbf{8 5 , 7}$ & $\mathbf{4}$ & $\mathbf{1 4 , 2}$ & $\mathbf{2 8}$ & $\mathbf{1 0 0}$ \\
\hline & & & & & & \\
WAKTU & & & & & & \\
ISTIRAHAT & & & & - & 6 & 21,4 \\
2-4 Jam/Hari & 6 & 21,4 & - & $-10,7$ & 17 & 60,7 \\
5-7 Jam/Hari & 14 & 50 & 3 & 10,5 \\
8-10 Jam/hari & 4 & 14,2 & 1 & 3,5 & 5 & 17,8 \\
\hline Total & $\mathbf{2 4}$ & $\mathbf{8 5 , 7}$ & $\mathbf{4}$ & $\mathbf{1 4 , 2}$ & $\mathbf{2 8}$ & $\mathbf{1 0 0}$ \\
\hline
\end{tabular}

Berdasarkan karakteristik umur, didapatkan hasil pada umur 20-30 tahun yang memiliki kadar hemoglobin rendah sebanyak (3,5\%) dan yang memiliki kadar hemoglobin normal sebesar (25\%). Umur 31-40 tahun yang memiliki hemoglobin rendah sebanyak (3,5\%) dan yang memiliki kadar hemoglobin normal sebesar $(35,7 \%)$, umur 41-50 tahun dengan yang memiliki kadar hemoglobin rendah $0 \%$ dan yang memiliki kadar hemoglobin normal (14,2\%), umur 51-60 tahun yang memiliki kadar hemoglobin rendah sebanyak $(7,1 \%)$ dan yang memiliki kadar hemoglobin normal sebesar (10,7\%).

Berdasarkan karakteristik umur dapat dilihat bahwa pada umur 51-60 tahun didapatkan persentase hemoglobin rendah lebih banyak $(7,1 \%)$ dibandingkan umur $<50$ tahun. Hal tersebut sejalan dengan penelitian Guralnik et al. (2004) yang menyatakan bahwa tingkat prevalensi lakilaki dengan anemia pada usia paruh baya
(>50 tahun) meningkat lebih cepat dibandingkan perempuan setelah usia 75 tahun dan mencapai prevalensi tertinggi yaitu $26 \%$ pada usia 85 tahun. Nordin et al. (2004) juga membuktikan bahwa adanya hubungan yang signifikan secara statistik antara kadar hemoglobin dengan usia, dimana ditemukan penurunan kadar hemoglobin mencapai $1,0 \mathrm{~g} / \mathrm{dl}$ per tahun pada laki-laki [11] [12]

Anemia pada orang usia lanjut dapat terjadi karena kurangnya asupan nutrisi seperti zat besi, B12, asam folat. Pada perokok, asupan zat gizi makro dan mikro cenderung tidak adekuat akibat penurunan nafsu makan. Nikotin, memiliki sifat adiktif dan mengakibatkan dampak fisiologis seperti perubahan pola makan. Penelitian yang dilakukan oleh Aginta (2011) menyatakan terdapat hubungan yang signifikan antara status gizi dengan kebiasaan merokok. Begitu juga dengan penelitian yang dilakukan oleh Dara et al. (2011) yang menyatakan terdapat hubungan yang signifikan antara lama merokok, jenis dan jumlah rokok dengan asupan makan (energi, karbohidrat, lemak, protein) dan status gizi terhadap kejadian anemia[13] [14]

Berdasarkan lama merokok didapatkan hasil kadar hemoglobin rendah paling banyak ditemukan pada orang yang merokok 1-10 tahun dengan jumlah 2 orang 
$(7,1 \%)$ dan $>20$ tahun dengan jumlah sebanyak 2 orang $(7,1 \%)$, sedangkan pada orang yang merokok 11-20 tahun tidak ditemukan kadar hemoglobin rendah. Hal tersebut selaras dengan penelitian yang dilakukan oleh Amelia et al. (2016) terhadap 65 orang pendonor darah di Palang Merah Indonesia, menemukan bahwa tidak terdapat hubungan bermakna antara lama merokok dengan kadar hemoglobin[15]

Berdasarkan jumlah rokok yang dihisap setiap hari diperoleh hasil hemoglobin rendah paling banyak ditemukan pada orang yang merokok >20 batang/hari dengan jumlah 2 orang $(7,1 \%)$. Hal ini menunjukkan bahwa semakin banyak rokok yang dihisap setiap harinya maka memungkinkan semakin banyak asap rokok yang dihirup. Anindyajati (2007) telah membuktikan bahwa mencit (Mus muskullus I.) yang dipaparkan asap yang mengandung Karbonmonoksida selama 9 jam/hari menyebabkan penurunan kadar hemoglobin. Gas karbonmonoksida (CO) bersifat toksis yang berlawanan dengan oksigen dalam transport maupun penggunaannya. Dalam rokok terdapat karbonmonoksida 2-6\% pada saat merokok, sedangkan Karbonmonoksida yang dihisap oleh perokok paling rendah sebanyak 400 ppm (parts per million) sudah dapat

\section{Profil Indeks Eritrosit}

Adapun profil indeks eritrosit pada perokok aktif adalah sebagai berikut :

a) Profil indeks eritrosit berdasarkan kelompok umur. meningkatkan kadar karboksi hemoglobin dalam darah sebanyak 2-16\%. Gas Karbonmonoksida dapat pula menimbulkan denaturasi hemoglobin, menurunkan langsung persediaan oksigen untuk jaringan seluruh tubuh termasuk miokard. [16] [5]

Berdasarkan waktu istirahat pada penelitian ini didapatkan orang yang tidur dibawah 8 jam/hari memiliki kadar hemoglobin yang lebih rendah. Tidur merupakan proses yang sangat dibutuhkan oleh tubuh untuk pembentukan sel-sel yang rusak, memberi waktu organ tubuh untuk beristirahat maupun untuk menjaga keseimbangan metabolisme dan biokimiawi tubuh. Kualitas tidur yang kurang akan berdampak bagi tubuh karena proses biologis yang terjadi saat tidur akan terganggu antara lain dalam hal pembentukan hemoglobin sehingga kadar hemoglobin menjadi rendah. Hal tersebut selaras dengan hasil penelitian Sarjono, et al. (2016) membuktikan bahwa terdapat 35 orang $(49,3 \%)$ kadar hemoglobin dibawah normal dimiliki oleh orang-orang dengan kualitas tidur yang buruk [17] 
Tabel 2. Profil indeks eritrosit berdasarkan umur pada perokok aktif di Kelurahan Tanjung Pinang Kota Palangka Raya tahun 2018

\begin{tabular}{|c|c|c|c|c|c|c|c|c|c|c|c|c|c|c|c|c|c|c|}
\hline \multirow{3}{*}{ UMUR } & \multicolumn{6}{|c|}{ MCV } & \multicolumn{6}{|c|}{$\mathrm{MCH}$} & \multicolumn{6}{|c|}{$\mathrm{MCHC}$} \\
\hline & \multicolumn{2}{|c|}{ Normal } & \multicolumn{2}{|c|}{ Tinggi } & \multicolumn{2}{|c|}{ Rendah } & \multicolumn{2}{|c|}{ Normal } & \multicolumn{2}{|c|}{ Tinggi } & \multicolumn{2}{|c|}{ Rendah } & \multicolumn{2}{|c|}{ Normal } & \multicolumn{2}{|c|}{ Tinggi } & \multicolumn{2}{|c|}{ Rendah } \\
\hline & $\mathrm{n}$ & $\%$ & $\mathrm{n}$ & $\%$ & $\mathrm{n}$ & $\%$ & $n$ & $\%$ & $n$ & $\%$ & $\mathrm{~N}$ & $\%$ & $\mathrm{n}$ & $\%$ & $\mathrm{n}$ & $\%$ & $\mathrm{n}$ & $\%$ \\
\hline 20-30 Tahun & 7 & 25 & 0 & 0 & 1 & 3,5 & 7 & 25 & 0 & 0 & 0 & 0 & 5 & 17,8 & 2 & 7,1 & 0 & 0 \\
\hline 31-40 Tahun & 9 & 32 & 0 & 0 & 2 & 7,1 & 10 & 35 & 0 & 0 & 1 & 3,5 & 10 & 35 & 1 & 3,5 & 0 & 0 \\
\hline 41-50 Tahun & 3 & $\begin{array}{c}10 \\
7\end{array}$ & 0 & 0 & 1 & 3,5 & 4 & 14 & 0 & 0 & 0 & 0 & 3 & 10,7 & 1 & 3,5 & 0 & 0 \\
\hline 51-60 Tahun & 4 & 14 & 0 & 0 & 1 & 3,5 & 4 & 14 & 0 & 0 & 1 & 3.5 & 4 & 14 & 1 & 3,5 & 0 & 0 \\
\hline Total & 23 & 82 & 0 & 0 & 5 & 17,8 & 25 & 89 & 0 & 0 & 2 & 7,1 & 22 & 78,5 & 5 & 17,8 & 0 & 0 \\
\hline
\end{tabular}

b) Profil indeks eritrosit berdasarkan lama merokok.

Tabel 3. Profil indeks eritrosit berdasarkan lama merokok pada perokok diKelurahan Tanjung Pinang Kota Palangka Raya tahun 2018

\begin{tabular}{|c|c|c|c|c|c|c|c|c|c|c|c|c|c|c|c|c|c|c|}
\hline \multirow{3}{*}{$\begin{array}{c}\text { LAMA } \\
\text { MEROKOK }\end{array}$} & \multicolumn{6}{|c|}{ MCV } & \multicolumn{8}{|c|}{$\mathrm{MCH}$} & \multicolumn{4}{|c|}{$\mathrm{MCHC}$} \\
\hline & \multicolumn{2}{|c|}{ Normal } & \multicolumn{2}{|c|}{ Tinggi } & \multicolumn{2}{|c|}{ Rendah } & \multicolumn{2}{|c|}{ Normal } & \multicolumn{2}{|c|}{ Tinggi } & \multicolumn{2}{|c|}{ Rendah } & \multicolumn{2}{|c|}{ Normal } & \multicolumn{2}{|c|}{ Tinggi } & \multicolumn{2}{|c|}{ Rendah } \\
\hline & $\mathrm{n}$ & $\%$ & $\mathrm{n}$ & $\%$ & $\mathrm{n}$ & $\%$ & $\mathrm{n}$ & $\%$ & $\mathrm{n}$ & $\%$ & $\mathrm{n}$ & $\%$ & $\mathrm{n}$ & $\%$ & $\mathrm{n}$ & $\%$ & $n$ & $\%$ \\
\hline 1-10 Tahun & 7 & 25 & 0 & 0 & 2 & 7,1 & 8 & 28 & 0 & 0 & 1 & 3,5 & 7 & 25 & 2 & 7,1 & 0 & 0 \\
\hline 11-20 Tahun & 8 & 28 & 0 & 0 & 1 & 3,5 & 9 & 32 & 0 & 0 & 0 & 0 & 9 & 32 & 0 & 0 & 0 & 0 \\
\hline >20 Tahun & 8 & 28 & 0 & 0 & 2 & 7,1 & 9 & 32 & 0 & 0 & 1 & 3,5 & 7 & 25 & 3 & 10,7 & 0 & 0 \\
\hline Total & 23 & 82,1 & 0 & 0 & 4 & 14,2 & 26 & 92,8 & 0 & 0 & 2 & 7,1 & 23 & 82 & 5 & 17,8 & 0 & 0 \\
\hline
\end{tabular}

c) Profil indeks eritrosit berdasarkan jumlah batang yang dihisap per hari.

Tabel 4. Profil indeks eritrosit berdasarkan jumlah rokok yang dihisap setiap hari pada perokok aktif di Kelurahan Tanjung Pinang Kota Palangka Raya

\begin{tabular}{|c|c|c|c|c|c|c|c|c|c|c|c|c|c|c|c|c|c|c|}
\hline \multirow{3}{*}{$\begin{array}{l}\text { JUMLAH } \\
\text { ROKOK }\end{array}$} & \multicolumn{6}{|c|}{ MCV } & \multicolumn{6}{|c|}{$\mathrm{MCH}$} & \multicolumn{6}{|c|}{$\mathrm{MCHC}$} \\
\hline & \multicolumn{2}{|c|}{ Normal } & \multicolumn{2}{|c|}{ Tinggi } & \multicolumn{2}{|c|}{ Rendah } & \multicolumn{2}{|c|}{ Normal } & \multicolumn{2}{|c|}{$\begin{array}{c}\text { Tingg } \\
\text { i }\end{array}$} & \multicolumn{2}{|c|}{ Rendah } & \multicolumn{2}{|c|}{ Normal } & \multicolumn{2}{|c|}{ Tinggi } & \multicolumn{2}{|c|}{ Rendah } \\
\hline & $\mathrm{n}$ & $\%$ & $\mathrm{n}$ & $\%$ & $\mathrm{n}$ & $\%$ & $\mathrm{n}$ & $\%$ & $\mathrm{n}$ & $\%$ & $\mathrm{n}$ & $\%$ & $\mathrm{n}$ & $\%$ & $\mathrm{n}$ & $\%$ & $\mathrm{n}$ & $\%$ \\
\hline 1-10 Batang & 6 & 21,4 & 0 & 0 & 2 & 7,1 & 7 & 25 & 0 & 0 & 1 & 3,5 & 6 & 21,4 & 2 & 7,1 & 0 & 0 \\
\hline 11-20 Batang & 9 & 32 & 0 & 0 & 1 & 3,5 & 10 & 35 & 0 & 0 & 1 & 3,5 & 9 & 32 & 1 & 3,5 & 0 & 0 \\
\hline >20 Batang & 8 & 28 & 0 & 0 & 2 & 7,1 & 9 & 32 & 0 & 0 & 1 & 3,5 & 9 & 32 & 1 & 3,5 & 0 & 0 \\
\hline Total & 23 & 82,1 & 0 & 0 & 4 & 14,2 & 26 & 92,8 & 0 & 0 & 3 & 10,7 & 24 & 85,7 & 4 & 14 & 0 & 0 \\
\hline
\end{tabular}

d) Profil indeks eritrosit berdasarkan waktu istirahat.

Tabel 5. Profil indeks eritrosit berdasarkan waktu istirahat pada perokok aktif di Kelurahan Tanjung Pinang Kota Palangka Raya 


\begin{tabular}{|c|c|c|c|c|c|c|c|c|c|c|c|c|c|c|c|c|c|c|}
\hline \multirow{3}{*}{$\begin{array}{l}\text { WAKTU } \\
\text { ISTIRAHAT }\end{array}$} & \multicolumn{6}{|c|}{$\mathrm{MCV}$} & \multicolumn{6}{|c|}{$\mathrm{MCH}$} & \multicolumn{6}{|c|}{$\mathrm{MCHC}$} \\
\hline & \multicolumn{2}{|c|}{ Normal } & \multicolumn{2}{|c|}{ Tinggi } & \multicolumn{2}{|c|}{ Rendah } & \multicolumn{2}{|c|}{ Normal } & \multicolumn{2}{|c|}{ Tinggi } & \multicolumn{2}{|c|}{$\begin{array}{c}\text { Renda } \\
\mathrm{h}\end{array}$} & \multicolumn{2}{|c|}{ Normal } & \multicolumn{2}{|c|}{ Tinggi } & \multicolumn{2}{|c|}{ Rendah } \\
\hline & $\mathrm{n}$ & $\%$ & $\mathrm{n}$ & $\%$ & $\mathrm{n}$ & $\%$ & $\mathrm{~N}$ & $\%$ & $n$ & $\%$ & $n$ & $\%$ & $\mathrm{n}$ & $\%$ & $\mathrm{n}$ & $\%$ & $n$ & $\%$ \\
\hline 2-4 jam/hari & 6 & 21 & 0 & 0 & 0 & 0 & 6 & 21 & 0 & 0 & 0 & 0 & 4 & 14 & 2 & 7,1 & 0 & 0 \\
\hline 5-7 jam/hari & 14 & 50 & 0 & 0 & 3 & 10,7 & 16 & 57 & 0 & 0 & 1 & 3,5 & 15 & 53 & 2 & 7,1 & 0 & 0 \\
\hline $\begin{array}{l}\text { 8-10 } \\
\text { jam/hari }\end{array}$ & 3 & 10,7 & 0 & 0 & 2 & 7,1 & 4 & 14 & 0 & 0 & 1 & 3,5 & 4 & 14 & 1 & 3,7 & 0 & 0 \\
\hline Total & 23 & 82,1 & 0 & 0 & 5 & 17,8 & 26 & 92 & 0 & 0 & 2 & 7,1 & 23 & 82 & 5 & 17,8 & 0 & 0 \\
\hline
\end{tabular}

Berdasarkan karakteristik umur didapatkan nilai MCV rendah banyak ditemukan pada umur 31-40 tahun dengan jumlah sebanyak 2 orang $(7,1 \%)$, nilai $\mathrm{MCH}$ rendah ditemukan pada umur 31-40 tahun dan 51-60 tahun sebanyak 1 orang (3,5\%) dan nilai MCHC tinggi banyak ditemukan pada umur 20-30 tahun dengan jumlah sebanyak 2 orang $(7,1 \%)$.

Hal tersebut menunjukkan tidak ada hubungan yang bermakna antara umur dengan nilai indeks eritrosit. Hasil ini sejalan dengan penelitian Nordin et al. (2004) yang menyatakan bahwa tidak ada hubungan antara nilai MCV dan $\mathrm{MCH}$ dengan umur. ${ }^{12}$

Berdasarkan karakteristik lama merokok didapatkan MCV rendah banyak ditemukan pada orang yang merokok 1-10 tahun sebanyak 2 orang $(7,1 \%)$, dan $>20$ tahun sebanyak 2 orang $(7,1 \%)$, sedangkan untuk MCHC tinggi banyak ditemukan pada lama merokok >20 tahun dengan jumlah 3 orang $(7,1 \%)$. Hal ini sejalan dengan penelitian yang dilakukan oleh Kabier (2015) yang menemukan tingginya nilai $\mathrm{MCHC}$ pada orang yang merokok >10 tahun.
Berdasarkan karakteristik lama merokok nilai MCV rendah banyak ditemukan pada orang yang merokok 1-10 batang dan $>20$ batang dengan jumlah sebanyak 2 orang $(7,1 \%)$ dan nilai $\mathrm{MCHC}$ tinggi banyak ditemukan pada orang yang merokok 1-10 batang dengan jumlah 2 orang (7,1\%). Kabier (2015) dalam penelitiannya menyatakan orang yang merokok >10 batang per hari akan didapatkan hasil nilai MCV lebih tinggi, hal tersebut tidak sejalan dengan penelitian yang dilakukandimana dalam penelitian ini orang yang merokok $>10$ batang perhari mendapatkan nilai MCV rendah. Berdasarkan karakteristik waktu istirahat, orang dengan waktu istirahat kurang dari 8 jam memiliki nilai MCV rendah sebanyak 3 orang $(10,7 \%) \mathrm{MCH}$ rendah 1 orang $(3,5 \%)$, dan $\mathrm{MCHC}$ tinggi sebanyak 2 orang $(7,1 \%)[18]$ 


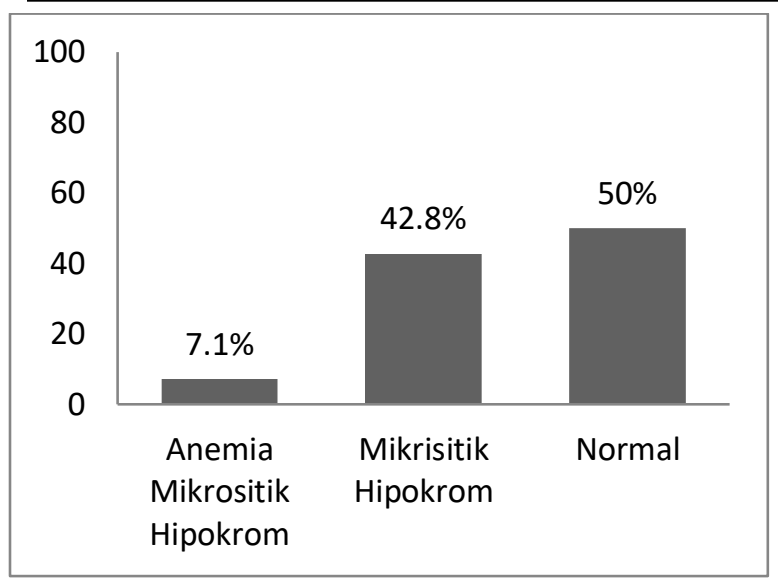

Gambar 1. Grafik Anemia 2018 (Data Primer)

Pada penelitian ini didapat hasil sebanyak $(7,1 \%)$ masuk dalam kategori anemia mikrositik hipokrom yang ditandai dengan kadar hemoglobin rendah, nilai MCV rendah, dan $\mathrm{MCH}$ rendah dan setelah dikonfirmasi dengan sediaan apusan darah tepi ditemukan sel mikrositik hipokrom. Anemia mikrositik hipokrom adalah keadaan dimana ukuran eritrosit lebih kecil dari pada normal (mikrositik), serta ditandai dengan hipokromik (central pallor melebar pada sediaan apusan). Anemia mikrositik hipokrom terjadi pada anemia defisiensi besi. Anemia defisiensi besi dapat terjadi akibat kekurangan kandungan zat besi. Zat besi yang tidak adekuat menyebabkan berkurangnya sintesis hemoglobin sehingga menghambat proses pematangan eritrosit. Zat besi yang tidak adekuat disebabkan oleh rendahnya asupan besi total dalam makanan atau ketersediaan besi yang dikonsumsi menurun, perdarahan kronis, diare kronik, malabsobsi, serta infeksi cacing tambang [19]

Komponen asap rokok seperti $\mathrm{Pb}$ dapat mengganggu sistem hemopitik pada sintesa heme melalui tiga mekanisme, yakni mengganggu penyatuan Glycine dan Succinyl Co-Enzyme A, melalui depresi terhadap delta-ALAD, dan melalui gangguan terhadap enzim Ferrochelatase yang berfungsi melekatkan besi $(\mathrm{Fe})$ terhadap protoporphyrin yang kemudian menjadi heme sebagai bagian dari hemoglobin. Sintesa hemoglobin yang berkurang akibat $\mathrm{Pb}$ dapat menimbulkan hipokromik pada eritrosit [20]. Selain itu kondisi hipoksia jaringan karena paparan CO yang masuk ke dalam tubuh dapat menyebabkan penurunan produksi hepcidin (suatu hormon yang mengontrol absorbsi besi) sehingga menurunkan produksi besi dalam plasma yang selanjutnya dapat menyebabkan terjadinya anemia defisiensi besi [21].

\section{KESIMPULAN}

1. Diperoleh sebanyak $14,2 \%$ kadar hemoglobin rendah dan $85,7 \%$ kadar hemoglobin normal.

2. Berdasarkan karakteristik lama merokok didapatkan kadar hemoglobin rendah banyak ditemukan pada orang yang merokok 1-10 tahun dan >20 tahun sebesar $7,1 \%$. 
3. Berdasarkan karakteristik jumlah rokok yang dihisap 1-10 batang per hari diperoleh kadar hemoglobin rendah sebanyak 3,5\%, 11-20 batang per hari sebanyak 3,5\%, dan $>20$ batang per hari sebanyak $7,1 \%$.

4. Berdasarkan karakteristik waktu istirahat, kadar hemoglobin rendah banyak ditemukan pada waktu istirahat 5-7 jam/hari sebesar 10,7\%.

5. Berdasarkan nilai indeks eritrosit ditemukan $7,1 \%$ (2 orang) dengan anemia mikrositik hipokrom $(\mathrm{MCH}$ rendah, MCV rendah, MCHC normal) disertai dengan kadar hemoglobin rendah.

\section{DAFTAR PUSTAKA}

1. Badan Penelitian dan Pengembangan Kesehatan. 2013. Riset Kesehatan Dasar 2013. Kementerian Kesehatan RI.

2. Badan Penelitian dan Pengembangan Kesehatan. 2007. Riset Kesehatan Dasar 2007. Kementerian Kesehatan RI.

3. Jaya, M. 2009. Pembunuh Berbahaya Itu Bernama Rokok. Yogyakarta : Penerbit Riz'ma.

4. Sudaryanto, T.W. 2015. Hubungan Antara Derajat Merokok Aktif, Ringan, Sedang, dan Berat dengan Kadar Saturasi Oksigen dalam Darah $\left(\mathrm{SpO}_{2}\right)$. Universitas Muhammadiyah Surakarta : Surakarta.

5. Irawati, L. 2011. Hubungan Jumlah dan Lamanya Merokok dengan Viskositas Darah. Majalah Kedokteran Andalas. 35 (2) : 137-146.

6. Ibrahim, K. M. Mulazim, H. B., Muhammad S. A., and Sharmaine, E. 2014. Effect of smoking on Red Blood Cells Count, Hemoglobin Concentration and Red Cell Indices: Pakistan Journal of Medical and Health Sciences. 361-364.
7. Lemeshow, S., David, W. H., Janelle, K., and Stephen, K. L. 1997. Besar Sampel Dalam Penelitian Kesehatan. Terjemahan Dibyo Pramono. Yogyakarta : Gadjah Mada University Press.

8. Departemen Kesehatan Republik Indonesia (DEPKES RI). 2008. Pedoman Praktek Laboratorium yang Benar (Good Laboratory Practice). Jakarta : Departemen Kesehatan Republik Indonesia.

9. Mengko, R. 2013. Instrumentasi Laboratorium Klinik. Bandung : Penerbit ITB.

10. Sysmex. Automated Hematology Analyzer XP-300 Instructions for Use. Japan : Sysmex Corporation.

11. Guralnik, J. M. Richard, S. E., Luigi, F., Harvey, G. K., and Richard, C. W. 2004. Prevalence of Anemia in Persons 65 Years and Older in The United States: Evidence For A High Rate of Unexplained Anemia. Blood Journal. 104 (8) : 22632268.

12. Nordin, G., Martensson, A., Swolin, B., et al. 2004. A multicentre study of Reference Intervals for Haemoglobin, Basic Blood Cell Counts and Erythrocyte Indices in The Adult Population of the Nordic Countries. Scandinavian Journal of Clinical and Laboratory Investigation. 64 : 385-398.

13. Aginta, E. 2011. Hubungan Antara Merokok dan Kebiasaan Makan dengan Status Gizi Remaja Putra. Universitas Diponegoro Semarang : Semarang.

14. Dara, A L, Burhanuddin B, Nurhaedar J. 2011. Kebiasaan Merokok dan Asupan Makanan Terhadap Status Gizi Manula Kelurahan Balla Kabupaten Enrekang. Universitas Hasanudin Makasar : Makassar.

15. Amelia, R. et al., 2016. Hubungan Derajat Merokok Berdasarkan Indeks Brinkman Dengan Kadar Hemoglobin. Jurnal Kesehatan Andalas. 5 (3) : 619-624.

16. Anindyajati. E. A. 2007. Pengaruh Asap Pelelehan Lilin Batik (Malam) Terhadap Struktur Histologis Trakea dan Alveoli Pulmo, Jumlah Eritrosit Serta Kadar 


\section{Profil Kadar Hemoglobin Dan Indeks Eritrosit Pada \\ Perokok Aktif Di Kelurahan Tanjung Pinang \\ Kota Palangka Raya}

Hemoglobin Mencit (Mus muscullus L). Universitas Sebelas Maret: Surakarta.

17. Sarjono, L., Pandelaki, dan Onkowijaya. 2016. Perbedaan Kadar Hemoglobin Pada Mahasiswa Fakultas Kedokteran Universitas Samratulangi Berdasarkan Kualitas Tidur. Jurnal e-Clinic (e-Cl). 4 (2) : 1-4.

18. Kabier, W.A.M.A. 2015. Determination of Some Hematological Parameters among Healthy Smokers in Khartoum State. Sudan University of Science and Technology.

19. Holly, B. F., and Schust, J. D. 2009. Reccuent Pregnancy Loss. Reviews In Obstetric and Gynecology.

20. Rizkiawati, A. 2012, Faktor-Faktor yang Berhubungan Dengan Kadar Hemoglobin (Hb) Dalam Darah Pada Tukang Becak Di Pasar Mranggen Demak : Demak. Jurnal Kesehatan Masyarakat. 1 (2) : 663-669.

21. Wimbley, J. D. J., and Graham, D. Y. 2011. Diagnosis and Managemen of Iron Deficiency Anemia in the $21^{\text {st }}$ Century. Therapeutic Advances Gastroenterology. 4 (3) : 177-184. 